\title{
From unimpeachable autonomy to self-imposed heteronomy: a liberal and Foucauldian perspective on advance euthanasia directives
}

\author{
Malte Kayßer (1D ${ }^{1,3 凶} \&$ Peter Wedekind (iD ${ }^{2,3 凶}$
}

\begin{abstract}
Based on a controversial case of assisted suicide offered to and eventually enforced on a demented woman vainly resisting the procedure, this article discusses the problems that arise when the human entity is conceptualized as an individual primarily defined by his ability for rational self-expression and autonomous self-rule. To highlight these difficulties, a liberal view on 'autonomy'-a term which serves as an ideal but is yet subject to conditions-is scrutinized. Given that liberal political theory alone is insufficient to fully reflect the changes of personality by which an individual's fight for autonomy bears the potential to turn into unalterable heteronomy, it is complemented by the thought of Michel Foucault. With his attention to societal mechanisms which bring individuals about-a process termed 'individuation' in the following-cases like the aforementioned scenario wherein individuals are forced to divide themselves from themselves can be critically analyzed. Such an approach illustrates that the established notion of the 'individual' can be led ad absurdum, and its validity as both an analytical idea and a normative vision should be challenged. As a result, there is a need for a more clairvoyant concept of the human person to be articulated, capable of conciliating the discontinuous nature of existence.
\end{abstract}

\footnotetext{
${ }^{1}$ Christian-Albrecht University of Kiel, Kiel, Germany. ${ }^{2}$ Charles University, Prague, Czech Republic. ${ }^{3}$ These authors contributed equally: Malte Kayßer, Peter

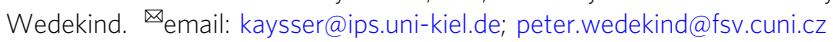




\section{Introduction}

n 2016 a 74-year-old woman was put to death in the Netherlands while showing signs of resistance. The scenery of this loss of life was no classical crime like a robbery gone wrong or a vile murder (Miller et al., 2019). Instead, this woman tried to resist a lethal injection by a medical doctor. In 2002 voluntary euthanasia was legalized in the Netherlands allowing patients whose suffering is judged to be unbearable to undergo assisted suicide (Miller et al., 2019). The abovementioned woman was eligible for such a procedure given she had been diagnosed with Alzheimer's disease-an irreversible brain disorder she was previously forced to witness in a family member deteriorating from dementia. Upon facing the same destiny, she wrote an 'advance euthanasia directive' (AED), wherein she stated:

"I want to make use of the legal right to undergo voluntary euthanasia when I am still at all mentally competent and am no longer able to live at home with my husband. I absolutely do not want to be placed in an institution for elderly dementia patients. I want to take a dignified farewell from my precious loved ones... Trusting that at the time when the quality of my life has ended up in the above-described situation, I would like to undergo voluntary euthanasia" (Miller et al., 2019).

Her condition worsened quickly, and her husband eventually admitted her to a nursing home where the geriatrician in charge was asked to honor her AED. After observing the patient's condition for one month, the geriatrician judged her suffering to be unbearable and decided to execute the euthanasia procedure (Miller et al., 2019). She placed a sedative in the woman's coffee without informing her "because she 'would have asked questions about (the sedative) and refused to take it" and also "because "the physician wanted to prevent a struggle during the euthanasia"” (Miller et al., 2019). Yet, during the lethal injection procedure the woman suddenly "tried to get up" in panic and the geriatrician asked the woman's family to "hold the patient in place" enabling her to administer the final dose (Miller et al., 2019).

It is not clear whether she suffocated consciously, and it is not even known if the patient truly understood that she was about to die. Yet, this woman clearly demonstrated a will of her own resisting the procedure under duress. This incident calls into question both if this eu thanatos, Ancient Greek for 'good death', indeed offered her the possibility of taking "a dignified farewell" from her precious loved ones in a "voluntary" manner, and whether the ethical guidelines were honored (Miller et al., 2019). The case was taken up by the Dutch euthanasia review committee which concluded "that the euthanasia was not performed in a medically careful manner", but the geriatrician was acquitted of all charges before the criminal court (Miller et al., 2019). Even the Dutch High Court followed the previous ruling arguing that a physician may respond to a written request for euthanasia made before someone develops advanced dementia "even if the patient's condition means they become unable to confirm that request" (Krever and Woodyatt, 2020). Correspondingly, the lawfully approved of the patient's life to be ended based on the AED even though she repeatedly stated "'But not just now, it's not so bad yet!" during the one month of surveillance in the nursing home (Miller et al., 2019). According to the geriatrician, the patient's "conflicting statements about euthanasia were 'not relevant' because they reflected her lack of awareness and insight" (Miller et al., 2019). The geriatrician concluded that even "if the patient had said at that moment: 'I don't want to die,' the physician would have continued with the termination of life" (Miller et al., 2019).

This controversial case provokes obvious but pressing questions: Is it morally acceptable to terminate a person's life who has laid down his will to die in an AED, but who at the time of executing the euthanasia is either unable to confirm his previous will or even attempts to resist the procedure? More abstractly speaking, is a present self allowed to lawfully bind its future self's will if that future self is judged to be not 'sane' any longer? Such questions have been subject to abstract philosophical as well as practical medicinal-ethical debates within the arena of the 'thenself versus now-self problem before (Blackhall et al., 1995; Cantor, 1992, 1993; de Beaufort and van de Vathost, 2016; Dworkin, 1986, 1993; Herskovits, 1995; Menzel and Steinbock, 2013; Post, 1995; Rohde et al., 1995; Thomasma, 1991). Underlying the different positions on the matter are assumptions on the psychological continuity of the human being's identity in question. Some scholars advocate a fundamental psychological discontinuity in case of severe dementia effectively dividing the selves into two distinct persons (Behuniak, 2011; Dresser, 1995; Perkins, 2007). The present autonomous self, so the argument goes, has the authority to override the potentially divergent judgement of its impaired future self. Ronald Dworkin (1993) and others imply that psychological identity is continuous even in case of severe dementia (Cooley, 2007; Demarco and Lipuma, 2016; Quante, 1999). He sees no new person arising but rather the capacity for rational judgement fading which, in turn, deprives an individual of his autonomy (Dworkin, 1993). In light of this threat, he views AEDs as a preventive mechanism that contracepts the danger of being trapped in a deteriorating mind and body with no hope of alleviation besides natural death (Dworkin, 1993). Following this view, AEDs mean self-determination when the self has lost its ability to truly decide for itself. Dworkin (1993) proposes the term "precedent autonomy"-a law given to oneself by oneself at a previous point in time.

Both arguments are deeply problematic when it comes to the common conceptualization of the term 'individual'. In the first argument, the individual is divided by Alzheimer's disease into two radically different entities, making it nonsensical to adhere to the notion of the same 'individual' characterizing these two persons. The now-self would have been an individual only until it is eventually divided, but then it has never truly been an individual in the first place but rather a 'to-be-divided'. Similarly, it seems misleading to describe the then-self as an individual if it came into effect by an operation that has divided it from the former now-self. In the second argument, psychological continuity is admittedly preserved but an inner division takes place via a temporal barrier between the now-self and the then-self nevertheless: The full capacity to decide in a rational manner is assigned to the now-self while denying the same capacity to the then-self. So, while a first division seems to occur at some point in future time-rendering the individual effectively a dividual-a second division takes place when a hierarchy is established between the rule of the now-self and the powerlessness of the then-self. The latter must abide, resistance notwithstanding, while the former rules supreme without an actual presence.

And yet the term 'individual' is ubiquitous, considering the official and institutional narratives not only about the 'smallest political unit' in society but also the substantial value liberal democracies attribute to individualism (van den Haar, 2009). Providing citizens with the greatest individual liberty and selfgovernance ranks among the most prominent goals in Western societies. Within this contrast, various challenging questions come to the surface: How can 'one' conceive of oneself as an individual considering the powerful societal mechanisms that urge to divide oneself? How is one to be considered an indivisible 'one' when coherent unity can only be achieved by the expulsion or suppression of incoherent parts? Is it truly feasible to cling to the term 'individual' when it comes to conceptualizing the human 
being within society and throughout time? Such adjacent questions set the stage for the philosophical arena of this article.

We first ask ourselves in what manner the 'individual' has been conceptualized in the canonical corpus of liberal political theory both analytically and normatively. Analytically, the 'individual' is embedded in the specified array of related concepts (individualism, liberty, coercion, autonomy) as an entity whose right to selfgovernment is tied to his capacity for self-government. Normatively, we depict the ideal type of the individual which liberalism formulates as one of the crucial political ends to be realised within Western society.

Second, we introduce a perspective on the 'individual' which is usually thought starkly at odds with liberalism, namely that of the French philosopher Michel Foucault. We argue that what is regularly conceived as his critical genealogy of the modern 'subject' can easily be reformulated into a likewise critical assessment of the process which generates individuals in the first place: the process of 'individuation'. This shift in perspective on the 'individual' and his ontogenesis allows us to return liberalism's conventional account of the individual and shed light on its tacit inconsistencies and the problematic contradictions which ultimately threaten at times to flip the aspiration for autonomy into the realization of an inescapable heteronomy-a 'law being given by someone other than the self if we translate directly from Ancient Greek. German enlightenment thinker Immanuel Kant (1993) describes heteronomy as follow: "If the will seeks the law that is to determine it anywhere but in the fitness of its maxims for its own legislation of universal laws, and if it thus goes outside of itself and seeks this law in the character of any of its objects, then heteronomy always results. The will, in that case, does not give itself the law, but the object does so because of its relation to the will." Not only allows Kant's definition to spot how heteronomy refers to a type of legislation that has its origins outside of the entity it governs. It also illustrates how heteronomy is an antagonist to autonomy-one of the most prominent features in the liberal tradition we discuss in the section "Individualism, freedom, autonomy, and coercion in the liberal tradition".

Thus, it is our hypothesis that if the liberal appreciation for the singular human being shall remain a lasting principle of Western politics, we need to stop taking the 'individual' as an ever-existing fact and turn our attention to the often unseen and sometimes questionable practices of 'individuation'. It is the way by which we generate individuals, and not the existence of individuals per se whose evaluation must decide the merits of a liberal project that were to persist.

\section{Individualism, freedom, autonomy, and coercion in the liberal tradition}

Every attempt to frame the liberal tradition we are maneuvering in and every endeavor to define the term "liberalism" are destined to disappoint. There are too many competing definitions to be found as to provide a satisfying idea of the nature and features of liberalism that every scholar in the field is willing to accept. Furthermore, in recent decades the quest for a definition has led to substantial confusion given that the term's meaning shifted significantly during the second half of the 20th century (van den Haar, 2009). As Gerald Gaus et al. (2003) argue, we must come to realize that "liberalism is more than one thing. On any close examination, it seems to fracture into a range of related but sometimes competing visions". In contemporary public policy debates, 'liberalism' typically refers to a new or revised brand of liberal doctrines (Gaus et al., 2003). Such a liberalism is usually associated with greater social justice as well as welfare state policies and it tends to call into question the intimate relationship between individual liberty and private property based on the mechanism of the market order (Gaus et al. 2003). Such reinterpretation of the term embodies an alternative vision of liberalism in opposition to John Locke's and Adam Smith's 'old' classical liberal framework as well as its revised neoliberal versions of Ludwig von Mises, Friedrich August von Hayek, and others (Wintrop, 1985). Fortunately, there is at least a set of basic principles to be found that most scholars of (classical) liberalism would agree upon: natural law, spontaneous order, rule of law, limited state, freedom, and individualism. The latter two embody not only the core principles within liberal doctrines but also the most important ideals with regard to a discussion of AEDs. This list of common liberal features is not at all exhaustive. As Nigel Ashford (2001) illustrates in his compact work, the "principles for a free society" also include civil society, democracy, equality, free enterprise, justice, peace, and tolerance.

Unlike the versions of collectivist or communitarian doctrines that are predominantly concerned with the wellbeing of the community, individualism emphasizes the rights and the value of the individual (van den Haar, 2009). In opposition to some critics' claim, individualism does not inherently deny the social nature of human beings nor the crucial importance of cooperation to ensure survival (van den Haar, 2009). Instead, it is a reflection of the conviction that the individual entity must be the 'ultimate unit' that political decision-making is based on (van den Haar, 2009). Such an ultimate political unit, in turn, ought to be endowed with individual liberty - a goal relentlessly defended by advocates of classical liberalism. Unsurprisingly, liberty as liberalism's eponymous core value is typically understood as the most significant condition for individuals to "deal with the challenges in life and for society to prosper" (van den Haar, 2009). And yet, it is worth noticing that (classical) liberals are not the only ones who claim to promote the freedom of citizens under their aegis. The quest for the maximization of liberty can be interpreted very differently and can, correspondingly, give rise to competing imperatives. Isaiah Berlin, probably the most prominent source for definitions of 'freedom', illustrates its meaning in both the 'negative' and the 'positive' sense. The idea hidden behind the two terms can be differentiated based on two questions. Negative liberty asks: What is "the area within which the subject ... is or should be left to do or be what he is able to do or be, without interference by other persons?" (Berlin, 2002). Such freedom refers to the absence of external obstacles, interferences, and constraints (Carter, 2019). To illustrate what positive liberty is concerned with, Berlin (2002), in turn, asks: "what, or who, is the source of control or interference that can determine someone to do, or be, this rather than that?" In its positive connotation, the opportunity to live a free life does not predominantly refer to the absence of external barriers. Instead, it has a Kantian taste: positive liberty refers to an individual's wish to be "his own master" (Berlin, 2002). It is a reflection of the inherent desire to be an end in oneself, rather than an instrument to other people's wills (Berlin, 2002). A free life ought to depend on an individual's own decisions led by his own reasons, wishes, goals, and purposes (Berlin, 2002). The topic at hand is affected by the way in which we think about both positive and negative liberty. A discussion of AEDs in liberal democracies is inevitably accompanied by the question to which extent an individual can (continue to) live free of external interference while truly being his own master.

To lay the groundwork for the subsequent section, there is another pair of concepts to be found that is of crucial importance within the liberal arena and the ethical implications of AEDs. Two additional terms that must appear in any discussion in the realms of individual freedom (and its limitation) are 'autonomy' and 'coercion'.

In modern political thought, substantial moral value has been granted to the individual, and crucial importance has been 
attributed to the preservation of his liberty (Feinberg, 1986; Kant, 1964; Wertheimer, 2002). Correspondingly, ideals such as autonomy, self-government, and self-determination have become dominant terms within the debates of political philosophy and public policy alike (Feinberg, 1986; Kant, 1964; Wertheimer, 2002). Autonomy-linguistically originating from the Ancient Greek autonomia for 'law by the self-most commonly refers to a state of self-rule in which an individual follows his own laws (Feinberg, 1986). Following the thought of Joseph Raz, Michael Blake (2001) concludes that autonomous agents are characterized by the capacity to develop their own relationships as well as their individual goals, and, correspondingly, they are the (predominant) authors of their own lives. However, autonomy-and these are crucial conditions within the discussion of AEDsdepends on the agents' cognitive faculties, and they must be enabled to choose from a set of options (Blake, 2001).

When it comes to the term 'coercion', one is destined to encounter a controversial and challenging terrain due to a wide variety of competing definitions (Stevens, 2005). Advocates of negative freedom seeking to maximize its range are tempted to demonize any type of policy that may infringe upon individual liberty. At the same time, there are proponents of benevolent versions of liberty-limitations to be found arguing that coercion is in fact "[...] expanding opportunities and assistance for all to lead healthy and productive lives" (Stevens, 2005). When it comes to assisted suicide, we may be willing to add the ability to end one's own life in a dignified manner via an AED to the list of positive outcomes coercion can provide us with. Since coercion addresses both moral judgements and empirical questions alike, it lacks an unambiguous definition (Macleod, 2008). Coercion as a libertylimiting mechanism is prima facie at odds with fundamental liberal principles such as autonomy, and, correspondingly, both the coercive act and the (moral) justifications deserve attention (Blake, 2001). Karl De Schweinitz (1957) provides an economic approximation of the term that mirrors a simple and intuitive definition: "Coercion may be defined as the act by which one individual (or group) compels another individual (or group) to behave in a way that conflicts with his (or its) preferences or conscience. It is, in other words, a means by which A controls the behavior of B" (De Schweinitz, 1957). Ironically, we must conclude that in the case of AEDs, A and B describe the same physical entity.

A critical interpretation of the 'individual' in Foucault's work After having discussed the position the individual' commonly occupies between the opposing concepts of 'autonomy' and 'coercion' within classical liberal thought, we now turn our attention to a thinker who is usually framed in stark contrast to the liberal tradition.

The issue of the 'individual' as the outcome of a foregoing 'individuation' is usually none associated closely with the thinking of Michel Foucault. Rather, scholars tend to take him by his own word according to which the goal of his work has been "to create a history of the different modes by which, in our culture, human beings are made subjects" (Foucault, 1982). Henceforth his legacy has been received by many as a way to critically analyze the processes of 'subjectification' in a genealogy of the modern 'subject' (Allen, 2009; Flynn, 1985; Keller, 1996).

This well-established tradition of reading Foucault notwithstanding, we want to ask in the following section whether his work bears the still dormant and promising potential to vigorously dissect the genesis of the modern 'individual' instead. After all, had he not marked in the very same essay as one of the "most original points" in the analysis of contemporary power relations those struggles "which question the status of the individual" and that are "struggles against the 'government by individualization' revolving around the question 'who are we?"” (Foucault, 1982). In that spirit, the thought of the individual is tenaciously apparent when Foucault continues to describe the power against which those struggles were directed:

"This form of power applies itself to immediate everyday life which categorizes the individual, marks him by his own individuality, attaches him to his own identity, imposes a law of truth on him which he must recognize, and which others have to recognize in him. It is a form of power which makes individuals subjects" (Foucault, 1982 [italicization by authors]).

We feel urged to rephrase: It is a form of power by which human beings are subjected to existence as individuals. Designating this operation 'subjectification' is not wrong, yet it would be more precise and more in line with the outcome this operation generates to call it 'individuation'. Such a reformulation does not contradict the argumentative core of said essay, namely Foucault's (1982) much cited definition of the subject: "There are two meanings of the word subject: subject to someone else by control and dependence and tied to his own identity or self-knowledge". In the case we are discussing, those two meanings operate in an intertwined manner. The rational past-self of the woman had proleptically 'tied' her assumed irrational future-self to a certain definition of her own identity (second meaning) by authorizing a third party-i.e., the medical staff-to effect 'control and dependence' with lethal consequences (first meaning) once her future-self had lost its sanity due to a deteriorating progression of her dementia.

In the years preceding Foucault's ascendance to the prestigious Collège de France in 1970, Foucault repeatedly concerned himself with the question on the relation between an 'author' and his 'work', most notably maybe in his piece "What is an Author?" (Foucault, 1984a). Therein he asked: "What is a work? What is this curious unity which we designate as a work? Of what elements is it composed? Is it not what the author has written?" (Foucault, 1984a). Noted, Foucault does not speak of a singular work an author may write, but of the over-arching oeuvre comprised of a plurality of singular works which an author may or may not produce in the service of his profession. But still, the answer feels intuitively easy since one is attempted to utter a "yes"- of course, the work consists of what the author has written. We would like to ask in an analogous manner: What is an individual? What is this curious unity which we designate as an individual? Of what elements is he composed? Is it not the composition of all instances said individual has acted out as hypostases of his existence? Yet things are not so self-evident as should become clear by invoking one of Foucault's favorite examples: the case of Friedrich Nietzsche.

For Foucault (2002), it is not the same relation of 'authorship' that exists between, on the one hand, the name 'Nietzsche' and, on the other, the "youthful biographies, the philological articles, Zarathustra, Ecce Homo, the letters, the scholastic dissertations, the last postcards signed 'Dionysos' or 'Kaiser Nietzsche', and the innumerable notebooks with their jumble of laundry bills and sketches for aphorisms". If we were to publish a complete edition of the work of Friedrich Nietzsche, we would have to decide where to draw the line that would declare the territory of authorship to have ended and beyond which only scriptural remnants linger, not deemed worthy of being included in a complete edition of Nietzsche's opus. The current undertaking of translating the Kritische Studienausgabe into English is indicative here: Its editors expand the original scope by adding three additional volumes which cover his early unpublished writings, his notebooks for his published works and the "complete notebooks from his final years". The coverage of those 'final years' ends in the winter of 1888/89 - although Nietzsche did not die until 1900. 
We must conclude that what ended in the winter of 1888/89 obviously was not the life of Friedrich Nietzsche. What ended, was his authorship. But writing he did not stop, no. He continued to send out postcards to his close friends, those which Foucault (1984a) cites of being signed with 'Dionysos' or 'Kaiser Nietzsche', yet the editors of the translation of the Kritische Studienausgabe do not extend authorship to these scriptural remnants despite the professed will of expanding it. As to the question why they did not, the answer appears to be undoubtedly clear: In January 1889 Nietzsche had his well-known mental breakdown in Turin. He never recovered from it and spent the last decade of his life in aberration. Nietzsche's authorship ended because he had lost his sanity. The decision of the editors not to include those postcards in the Kritische Studienausgabe confirms a thesis which Foucault (2002) ventured forth in the context of those initial questions concerning the 'unity' of an author's work: namely that it is "at once apparent that such a unity, far from being given immediately, is the result of an operation". Further, "the operation that determines the opus in its unity" is "interpretative" (Foucault, 2002). Thus "the oeuvre can be regarded neither as an immediate unity, nor as a certain unity, nor as a homogeneous unity" (Foucault, 2002).

Unity of Nietzsche's work did not offer itself to the world as the expression of an already pre-existing bond. This unity is the effect of an operation, which the editors undertook by summoning the corpus of Nietzsche's writings before a threshold. To pass beyond this threshold meant to pass from a realm of insignificant scribbling to a realm of significant writing. It is the latter where authorship rules. Passage would be granted to the greatest part of scripture after the yardstick of reason had been applied by the editors. Those who were unable to exhibit their sanity had to return to the limbus of madness.

\section{Discussion: from autonomy to heteronomy and the rupture of continuity}

Let us fully establish now the analogy we have in mind: There was the 74-year-old woman whose utterance of "But not just now, it's not so bad yet!" was not admitted to the order of rational discourse and who consequently had to die. And there was Nietzsche whose writings after his mental breakdown did not warrant inclusion in the complete edition of his works. Though a comparison might seem daring at first sight-after all, the first refusal had ushered in death, whereas the other one only shortened the Kritische Studienausgabe by maybe a sixteenth volume-we want to argue that the logic at play is the very same in both cases: what is to be observed is "the operation that determines the opus in its unity" and that operation determines the opus of personhood in case of the 74-yearold woman as it does determine the opus of authorship in case of Friedrich Nietzsche (Foucault, 2002). Thus, we argue that any opus, oeuvre or work is the effect of a foregoing individuation.

The opus of authorship would be a 'work' that consists of parts considered indivisible of this individuated 'work'. The opus of personhood would be a 'life' that consists of parts considered indivisible of this individuated 'life'. Further, it is to be noted that both individuations come about only for the price of a certain amputation, an expulsion of those parts threatening coherence, by professing a trait incompatible to the trait assumed to exist for those parts that shall not be parted. This trait guiding both operations of individuation is the trait of rational sanity being contrasted by the trait of irrational insanity. In consequence, we can subsume that "this curious unity" which we saw Foucault (1984a) marveling about is held together by the assumed capacity to hold a rational discourse.

Throwing another glance at the liberal tradition of defining the individual upon whose high esteem the Western jurisprudence claims to be founded, it soon becomes eminently clear that such a capacity to express one's will in a rational manner is tied to the foregoing and necessary self-mastery. And this is where we run into deep and paradoxical problems in the case of AEDs since the willful autonomy which is argued to be self-mastery's operating principle threatens to turn itself into a coercive heteronomy.

As illustrated before, both liberty and autonomy rank among the most prominent ideals commonly defended by advocates of a liberal tradition. Joel Feinberg (1986) suggests that "[w]hatever else we mean by autonomy [...], it must be a good and admirable thing to have, not only in itself but for its fruits-responsibility, self-esteem, and personal dignity. Autonomy so conceived is not merely a 'condition,' but a condition to which we aspire as an ideal". Autonomy as well as its fruits include a multitude of capabilities which people like to claim for themselves: self-possession, individuality, self-determination, self-legislation, moral authenticity, moral independence, integrity, self-control, selfreliance, initiative, and responsibility for oneself (Feinberg, 1986). The assumption that autonomy is a fundamental precondition for employing one's full faculties and should therefore be valued as an ideal is a persistent sentiment in moral philosophy (Glod, 2013; Le Grand and New, 2015). However, autonomy as an ideal is deeply intertwined with liberty.

For an autonomous agent's action to be truly the result of selfgovernment, freedom is a necessary requirement (in opposition to coercion which undermines an individual's autonomy): "Coercion and manipulation [...] reduces the will of one person to the will of another; they are marked as violations of autonomy not simply in virtue of that fact, but because of the symbolic gesture this fact represents" (Blake, 2001). Feinberg brought forth a similar idea and adds that the existence of autonomy is based on conditions: for an autonomous agent to have a claim to selfgovernment, such an individual must also have the capacity to lead a self-governed life (Feinberg, 1986). This capacity, however, is in turn determined by the ability to act in accordance with rationality and, as a result, may exclude people with impaired or (not yet) fully developed mental faculties (children, mentally ill people, etc.) (Feinberg, 1986). Autonomy is frequently linked to a self-determined life, happiness, flourishing, and dignity. Kant (1964) goes as far as to insist that no autonomous individual must be coerced to seek happiness in a way that was forced upon him by any external agent. Instead, every autonomous person should engage in a distinct quest for fulfillment guided by his own goals and purposes, and such an individual's freedom should be limited only to ensure that all other autonomous agents have the same liberties (Kant, 1964). It becomes evident again that a Kantian angle on the potentially questionable implications AEDs can impose is closely related both to Feinberg's reasoning, and to Berlin's fundamental groundwork on 'positive' and 'negative' freedom introduced in section II. Kant's advocacy for liberty inescapably requires the autonomous individual to be free in the negative sense (i.e., to be free from external obstacles, barriers, and constraints) and to be free in the positive sense (roughly referring to the capacity for self-mastery). Similar to Feinberg's argument, Kant's vision of autonomy is, in turn, linked to certain conditions, suggesting that autonomy is "[...] a property of the will of rational beings" (Hill, 1991). As Thomas E. Hill Jr. (1991) explains, to "have a will is to be able to cause events in accord with principles. That is, a rational being has a will insofar as he can 'make things happen' ... To have autonomy it is also necessary to one's will to be free in a negative sense".

The mere existence of liberty limitations is neither evitable nor is it harmful to the principle of autonomy in general. The variety of options for an individual to choose from can be narrowed by all sorts of factors, including poverty or starvation (Blake, 2001). And yet, the true moral quarrel a liberal may have with AEDs lies 
within the 'artificial' deprivations of options and choices via an external agent or institutional arrangement euthanizing a person that previously agreed to the procedure but now resists its execution. Such a person or institution is doubting the ability of an individual to choose for himself, and his individual capacity to create value for himself is undermined (Blake, 2001):

"The idea of autonomy reflects an image of individual human agents as creating value by their creative engagement with the world; their allegiances, choices, and relationships constitute sources of value. This creation of value can be destroyed or respected by institutions in the world. The principle of autonomy, that is, relies upon a normative conception of human agents as entities who can take part not simply in practical reasoning about what actions to undertake, but in reflective deliberation about what values and ideals to endorse and pursue" (Blake, 2001).

The debate on justifications for liberty limitations-even in self-imposed scenarios-has problematic ethical implications for AEDs due to the tainted character of coercion which may be necessary to execute 'voluntary' euthanasia. Coercion expresses "[...] a relationship of domination, violating the autonomy of the individual by replacing that individual's chosen plans and pursuits with those of another" (Blake, 2001). Such domination is deeply at odds with the liberal principle of autonomy but yet an important feature of voluntary euthanasia laws-even though the idea of giving ourselves laws for the future is not entirely new (Blake, 2001).

The ability to anticipate a state in which one's own judgement may be impaired belongs to the fundamental convictions that have shaped certain interpretations of John Stuart Mill's harmprinciple. It is based on the claim that an impaired self must not harm an unimpaired self (Mill, 2009). We find it easy to imagine scenarios in which we would be willing to infringe upon a person's free action-for example a suicidal person about to jump off a bridge (Mill, 2009). Presumably, we would argue that such individual's judgement is currently clouded by duress or despair, concluding that his decision-making is radically altered in comparison to his calm and rational self. A related dichotomy is to be found in Thomas Schelling's idea of the "two selves" and its repercussions for political philosophy (Wertheimer, 2002). Of similar characteristics is the self-imposed liberty limitation of Odysseus, motivated by his attempt to listen to the sirens' song without falling prey to their call-anticipation of his own lack of voluntariness (Wertheimer, 2002).

The idea that an individual-an entity that is supposed to be undividable by definition-can be separated into different selves with the ability to impose restrictions upon each other is no genuine innovation. Every time we set an alarm clock, we are imposing restrictions on our future self that, the next morning, wants nothing more than to enjoy another hour of sleep. And yet, in the particular case of AEDs it is worth contrasting an individual's autonomy with the heteronomy an 'individual' may potentially find himself trapped in due to a division of the selves based on his capacity for rationality (and a lack thereof). There is a paradoxical contradiction to be found between 'autonomy' and the 'individual' defined as inalienable or undividable ideals on the one hand, and the myriad of deviations from such wishful archetypes on the other. Even Mill himself faced the challenge of reconciling unimpeachable autonomy with a pinch of humaneness in a paternalistic attempt to avoid at least the most severe instances of self-harming behavior when an agent's judgement is just too impaired (Le Grand and New, 2015). Correspondingly, it is not necessary to leave the arena of liberal thought to illustrate how AEDs are a uniquely fascinating case, given that they allow people to deprive themselves of their self-governance with quite literally deadly consequences. They brilliantly highlight the problems we are facing when we understand autonomy as an ideal and yet require it to meet a set of conditions in the shape of rationality or reason. And yet, the discussion receives another important perspective once we complement it with a Foucauldian point of view in the subsequent paragraphs.

AEDs seem to be at odds with individual liberty both in the positive and in the negative sense, and Berlin illustrates the important link between freedom, autonomy, and rationality in a truly rich elaboration:

"This is at least part of what I mean when I say that I am rational, and that it is my reason that distinguishes me as a human being from the rest of the world. I wish, above all, to be conscious of myself as a thinking, willing, active being, bearing responsibility for my choices and able to explain them by reference to my own ideas and purposes. I feel free to the degree that I believe this to be true, and enslaved to the degree that I am made to realize that it is not" (Berlin, 2002).

This portrayal of rationality and freedom's conjunction is fascinating if we further scrutinize the ability ascribed to rationality by Berlin (2002) to distinguish "me as a human being from the rest of the world". With a focus on the process of individuation, the case of AEDs highlights a disturbing potential. What if the reason was also to possess the ability not only to distinguish ourselves as human beings from the world but also from future emanations of our self that are deemed incompatible with our present reasonable self because they are judged unreasonable? The decisive 'cut' that would have allowed, analytically and normatively, to assert the prevalence of an independent individual against the collective would find itself mirrored and relayed into the human being itself, effectively dividing it into two. Thus, sparking the question if to still speak of the 'individual' does not occult a procedure that turns the autonomy of the 'individual' into the heteronomy of and by another person.

In the introduction to his early monograph History of Madness Foucault (2006a) had defined madness in a curious manner as "nothing other than the absence of an cuvre". We, in turn, conceptualize individuation as that 'work' by which parts considered indivisible from one another are molded into the 'individual' which the liberal tradition ex-post-facto has spent considerable effort to define and to defend in its normative esteem. In this view, could we not term AEDs as the attempt to proactively declare the inability of a future self's unreasonable version to contribute to the 'work' (œuvre) of being the assumed reasonable individual? Then, should we not regard AEDs as a declaration of will guided by reason which would have to be executed in that very moment when the 'work' representing reason could only be regarded as 'absent' for good and therefore madness being 'present' without hope of remedy?

Further along the History of Madness we find Foucault giving an account of the establishment of the psychiatric asylum in the $19^{\text {th }}$ century: Those people riveted by madness are usually assumed to have fared better and been treated more humane compared to their respective state in "the fortresses of confinement" of the $17^{\text {th }}$ and $18^{\text {th }}$ century in which those judged to be gone beyond recovery were often simply chained to the wall and left to their natural demise (Foucault, 2006a). The psychiatric asylum mostly refrained from exerting physical force on its inhabitants and offered a very specific contract to its patients: Instead of being declared mad and treated accordingly by the outside world, the mad were to conduct a thorough and on-going effort of introspection to become judges on themselves (Foucault, 2006a). They were to assume the self-responsibility to control and discipline their potentially mad affects in an increasing manner to slowly turn this 'territory' of their self that is only sparsely populated by outposts of reason once again into their fully controlled and therefore autonomous dominion (Foucault, 2006a). To summarize this short historical excursion, Foucault (2006a) 
claims that whereas before the institution of the psychiatric asylum the mad found themselves in front of an external court, now this trial to determine the state of their digression from reason has shifted its location into the accused person himself. This trial was to be held everlastingly and without recess (Foucault, 2006a). Following this argument, it can be said that the external punishments or the threat thereof could only have come to an end once the outward court had been convinced that the inward court had taken over the task of rigid observance, firm judgement, and relentless punishment, once "they were sure that it would continue indefinitely inside the patient's conscience" (Foucault, 2006a).

We want to put forward the tentative hypothesis that AEDs operate in a further refined version of this logic. As it stands now, a self is not asked to judge on its present state but to do so in advance confronted with the potential prospect of severe corporeal and psychic detriments such as progressing dementia would qualify to be.

If we now take up again the cue of transposing Berlin's distinction between human being and world (by virtue of rationality) into the human being itself-thus effectively splitting the individual 'one' into a divided 'two'-we could do the very same with other concepts that were originally brought to the fore to substantiate this outward-directed distinction. Let us reconsider Blake's (2001) argument on autonomy as to which the latter would be marked violated if "the will of one person" was reduced "to the will of another". Or Kant's (1964) insistence that no autonomous individual must be coerced to seek happiness in a way that was forced upon him by any external agent. And, finally, Hill's (1991) note that autonomy can only be assumed to be present if the will of the individual in question is regarded to "be free in a negative sense". The logic of an external source of potential coercion an individual must be guarded against is now likewise transposed into the human being itself. In his own internal arena, the agent at jeopardy of being coerced is a future version of the current self that is obsessed by a mental illness which prevents that human being to live and die in a selfinduced and autonomous manner. To prevent such mental imprisonment an AED is laid out which, paradoxically, authorizes the lawful coercion by external agents (i.e., the medical staff) to counter the future self s coercive power - even if the price for this goal is death.

We can now take up the aforementioned 'then-self vs. nowself problem and move along the line of assuming (at least) two distinct persons in consequence of the personality-altering potential of conditions such as dementia, brain-tumors, schizophrenia, or multiple personality disorders. Then we would have to ask in earnest, whether it is not this 'new' person who should assume the right to define for himself autonomously new criteria for a bearable life. Otherwise said person would be the victim of utmost heteronomy: namely being sentenced to death according to the unmet criteria of a bearable life instituted by another person.

Even reference to the above-mentioned harm principle by Mill could not ease our liberal conscience. Surely, the claim that an impaired self must not harm an unimpaired self has its validity for certain situations in life-suicide or drunkenness being typical examples thereof. Yet, their logic does not fully apply to the case of AEDs. What Mill thought of and what references to his argument most often have in mind are indeed temporary situations of duress during which judgement is 'currently' clouded. In these cases, there is hope for alleviation and a return to that 'unimpaired' self, if the suicide is prevented or the inebriety slept off-just as Odysseus had hoped to return home by evading the lure of Scylla and Charybdis. However, if dementia was the cliffs our Odysseus should not crush into, their presence would appear to be no single narrow bottleneck to stir the ship through but an unending canyon in the face of whose disheartening infinity Odysseus' crew decides to end his and their misery by eventually swerving the steering wheel. If, in that situation, Odysseus would have wanted to enjoy that sight somewhat longer or maybe saw that following this channel would have led to another island than his former home and therefore screamed "'But not just now, it's not so bad yet!'”, his crew would not have heard him and wrecked the ship, nonetheless.

The question then ensues which additional manners of professing the (un-)bearability of life should be acknowledged if such a 'new' person has lost the ability to express himself by taking part in rational discourse but-this impairment notwithstanding-still features dimensions in life where this person enjoys apparent happiness. It is further to be asked if the canonical concept of 'rationality' is not in need of a substantial revision to enable a wider concept of 'individuality' which in fact manages to cope with the potentially drastic changes in personality to withstand the temptation to divide itself from what at first sight might appear as foreign and the threat of external coercion. It is not our aim to do away with the 'individual' and the high moral value the liberal tradition attributes to it. Instead, we want to call to attention the flipside of the bright understanding of individuality as the ground from which to promote our autonomous self-determination. Because, if undetected, the case of AEDs demonstrates aptly how the intent to preserve autonomy by projecting it into the future effectively turns into the lethal order of a heteronomy without any chance to appeal.

\section{Conclusion}

In the introduction, we posed the question whether AEDs are a morally acceptable tool for a person's life to be ended. And even though the scenario of the 74-year-old woman in the Netherlands mainly serves as an extreme case allowing us to dive into a debate on the shortcomings of a purely liberal conception of 'the individual', the question yet deserves an answer. Our attempt to provide an answer can be phrased like this: It may depend on the patient's type of disease. We have relatively little quarrel with AEDs to be executed in cases where the patient's personality is not (substantially) altered by the sickness. Examples may be neuromuscular diseases that gradually lead to the decline of the patients' control over their musculoskeletal system while leaving their 'minds' intact. Here, we would indeed argue that an AED may prevent an individual from being trapped in his own degenerating body. However, as our previous discussions indicate, the real problem arises when we find an individual suffering from a disease that affects his rationality, personality, preferences, and, broadly speaking, his idea of what constitutes a life worth living. If one accepts our previous arguments, it seems natural to conclude that such a patient is no longer truly an 'individual'-an entity that, by definition, cannot be divided. Instead, we find ourselves in a situation where a new self has come into existence and where honoring the AED laid down by its former self would correspond to a death sentence being imposed on a new, potentially radically different, helpless, and heteronomous person.

This short concluding remark on AEDs allows us to briefly answer a further question the observant reader may have stumbled upon: Why do we implicitly judge heteronomy to be a morally unfavorable condition? Our position is grounded both in the philosophical tradition we are maneuvering in, and in the practical implications, heteronomy can impose. Despite our willingness to incorporate Foucauldian reasoning into our arguments, we did not defect from the liberal arena fully. Heteronomy, so advocates of classical liberal principles and Kantianism would probably agree, is morally unacceptable simply because it 
is, unsurprisingly, at odds with autonomy. As a result, it wields the power to undermine liberal ideals such as self-government, self-ownership, and individual freedom. The problems such heteronomous acts can impose when applied to concrete (and admittedly: extreme) real-world cases are obvious, as illustrated before: In an anti-Kantian manner, one self is governed by the laws and values of the other self-with potentially appalling and literally deadly consequences. Let us now return to our broader discussion on 'the individual' and to our concluding remarks.

In maybe his best-known work Discipline and Punish Foucault had remarked that the scientific self-measurement of men from the 19th-century onwards clearly indicated "the appearance of a new modality of power in which each individual receives as his own status his own individuality, and in which he is linked by his status to the features, the measurements, the gaps, the 'marks' that characterize him and make him a 'case"' (Foucault, 1995). Seen in this light, 'individuality' is less the secure ground of an unalterable essence from which the singular human being freely encounters the world, but much more a self-imposed norm from which one is henceforth regarded 'indivisible'. If alterations in personality occur that seriously question the validity of the amassed self-knowledge, the norm of 'being oneself' is considered transgressed and sanctions are put in place to either correct the 'straying from oneself' or to cut off the incoherent part when a reversion to the status quo ante appears unattainable.

In this article, we have contemplated a case where the said operation to 'cut off the incoherent part' for the sake of preserving an autonomous individuality meant death. A demented woman, who had authored an 'advanced euthanasia directive' in case of Alzheimer's disease, attempted a futile resistance when the agreed-upon euthanasia procedure was enacted and thus died against the then professed will to live. This case highlighted the difficulty which the canonical political theory of liberalism finds itself in when it conceives of the 'individual' primarily to be shielded from the threat of coercion by external agents in order to preserve its autonomy. Once this normative logic is transposed from the inter-individual to the intra-individual level, liberal theory finds itself unable to receive of the altered personality other than such an external agent against whose coercion the antecedent rational individual must be defended-even if death is demanded for such an operation to succeed. Therefore, after having presented the analytical as well as a normative framework within which liberal theory usually conceptualizes the individual, we have amended its apparent myopia with a theory of individuation derived by the thinking of Michel Foucault. This turn to a postmodern philosopher has allowed us to see the danger which liberal theory runs the risk to succumb to when its aspired autonomy turns into lethal heteronomy. Viewed in this light, liberal political theory and an account of individuation inspired by Foucault, are less at odds to the degree of utmost incompatibility but rather are able to complement each other decisively.

'Individuality' as seen by Foucault is foremost the effect of a subjecting power operation from which one should free oneself. 'Individuality' as seen by liberal political theory is the foundational unit of democratic societies whose autonomy must be defended at any cost. If we were to go solely with Foucault, little good and little of the worth to be sustained could be found in contemporary times. For its greatest part, Foucault's analyses are thorough critiques of Western society which is declared to be infested by undetected power structures. Without insinuating too much affinity with his at times intellectual rival Jacques Derrida, we could say his thought offers a forceful and so very useful deconstruction but yet merely fragments for a reconstructive alternative if we think of shorter pieces such as "What is Critique?" or "What is Enlightenment?" (Foucault, 2006b, 1984b). Therein Foucault had declared the "desubjectification" and a "critical ontology of ourselves" to be the normative aspiration of his thought that would allow going beyond the "limits that are imposed on us" even if death is demanded yet without mentioning where such Kantian Ausgang would lead us to (Foucault, 2006b, 1984b). If instead, we were to wholeheartedly accept liberalism's account of the 'individual' we would be blind to its own unconscious and the therein slumbering danger to purify the 'individual' of seemingly incommensurate parts. Yet if we synergize these two perspectives, we gain the ability to see clearly both the potential as well as the detrimental threat of an emancipatory project which puts the freedom of the singular human being at its center. In times like these, when the identitarian right and the identitarian left make the concept of the autonomous individual come under fire, perspectives which are skeptical of the collectivist absorption of the individual are well-advised to seek untypical alliances. This article has been a first attempt to do so. Highlighting the potential in this extreme case of forced-through euthanasia, it should be asked whether comparable instances of problematic operations of individuation could not be found elsewhere in more quotidian spheres of an individual's life. Western societies will be better positioned to defend themselves against their enemies when endowed with the insight to comprehend where and when they fail to meet the normative goals they have set for themselves. A critical account of individuation as it has been laid out here could contribute to such a necessary introspection.

Received: 28 June 2021; Accepted: 4 October 2021; Published online: 03 November 2021

\section{References}

Allen A (2009) Discourse, power, and subjectification: the Foucault/Habermas debate reconsidered. Philos Forum 40(1):1-28. https://doi.org/10.1111/ j.1467-9191.2008.00314.x

Ashford N (2001) Principles for a free society. Blomberg \& Janson, Bromma

Behuniak SM (2011) The living dead? The construction of people with Alzheimer's disease as zombies. Ageing Soc 31(1):70-92. https://doi.org/10.1017/ S0144686X10000693

Berlin I (2002) Liberty: incorporating four essays on liberty. Oxford University Press, Oxford

Blackhall LJ et al. (1995) Ethnicity and attitudes toward patients autonomy. J Am Med Assoc 274:820-825

Blake M (2001) Distributive justice, state coercion, and autonomy. Philos Public Aff 30(3):257-296

Cantor NL (1992) Prospective autonomy: on the limits of shaping one's postcompetence medical fate. J Contemp Health Law Policy 13:34-48

Cantor NL (1993) Advance directives and the pursuit of death with dignity. Indiana University Press, Indiana

Carter I (2019) Positive and negative liberty. Stanf Encycl Philos Arch https:// plato.stanford.edu/archives/win2019/entries/liberty-positive-negative/. Accessed 22 Feb 2021

Cooley DR (2007) A Kantian Duty for the soon-to-be-demented to commit suicide. Am J Bioeth 7(6):37-44. https://doi.org/10.1080/15265160701347478

de Beaufort ID, van de Vathost S (2016) Dementia and assisted suicide and euthanasia. J Neurol 263:1463-1467. https://doi.org/10.1007/s00415-0168095-2

Demarco JP, Lipuma SH (2016) Dementia, advanced directives, and discontinuity of personality. Cambr Q Healthc Ethics 25:674-685. https://doi.org/10.1017/ S0963180116000396

Dresser R (1995) Dworkin on dementia: elegant theory, questionable policy. Hastings Center Rep 25(5):32-38. https://doi.org/10.2307/3527839

Dworkin R (1986) Autonomy and the demented self. Milbank Q 64(2):4-16

Dworkin R (1993) Life's dominion. An argument about abortion, euthanasia, and individual freedom. Alfred A. Knopf, New York

Feinberg J (1986) The moral limits of the criminal law: harm to self. Oxford University Press, New York

Flynn TR (1985) Truth and subjectification in the later Foucault. J Philos 82(10):531-540. https://doi.org/10.2307/2026360

Foucault M (2002) Archaeology of knowledge. Routledge, Abingdon

Foucault M (1995) Discipline and punish. Vintage Books, New York 
Foucault M (1982) The subject and power. In: Dreyfus H, Rabinow P (eds) Michel Foucault: beyond structuralism and hermeneutics. The University of Chicago Press, Chicago, pp. 208-226

Foucault M (1984a) What is an author? In: Rabinow P (ed) The Foucault reader. Pantheon Books, New York, pp. 101-120

Foucault M (1984b) What is enlightenment? In: Rabinow P (ed) The Foucault reader. Pantheon Books, New York, pp. 32-50

Foucault M (2006a) History of madness. Routledge, London

Foucault M (2006b) What is critique? In: Schmidt J (ed) What is enlightenment? Eighteenth-century answers and twentieth-century questions. University of California, Berkeley, pp. 382-398

Gaus G, Courtland SD, Schmidtz D (2003). Liberalism. Stanf Encycl Philos Arch. Available via https://plato.stanford.edu/archives/fall2020/entries/liberalism/. Accessed 11 Sept 2021

Glod W (2013) Against two modest conceptions of hard paternalism. Ethic Theory Moral Pract 16:409-422. https://doi.org/10.1007/s10677-012-9339-6

van den Haar E (2009) Classical liberalism and international relations theory: Hume, Smith, Mises, and Hayek. Palgrave Macmillan, New York

Herskovits E (1995) Struggling over subjectivity: debates about the "self" and Alzheimer's disease. Med Anthropol Q 9(2):146-164. https://doi.org/10.1525/ maq.1995.9.2.02a00030

Hill TE (1991) Autonomy and self-respect. Cambridge University Press, Cambridge

Kant I (1993) Grounding for the metaphysics of morals: with on a supposed right to lie because of philanthropic concerns. Hackett Publishing Company, Indianapolis/Cambridge

Kant I (1964) Schriften zur Anthropologie, Geschichtsphilosophie, Politik und Pädagogik. Suhrkamp, Frankfurt am Main

Keller KJ (1996) Subjectification and resistance in Foucault. SubStance 25(1):78-110. https://doi.org/10.2307/3685230.

Krever M, Woodyatt A (2020) Dutch Court allows euthanasia in advanced dementia cases. CNN. Available via https://edition.cnn.com/2020/04/22/ europe/netherlands-euthanasia-dementia-intl-scli/index.html. Accessed 25 Apr 2021

Le Grand J, New B (2015) Government paternalism: nanny state or helpful friend? Princeton University Press, Princeton

Macleod AM (2008) Coercion, justice, and democracy. In: Reidy DA, Riker WJ (eds) Coercion and the state. Springer, Dordrecht, pp. 63-75

Menzel PT, Steinbock B (2013) Advance directives, dementia, and physician-assisted death. J Law Med Eth41(2):484-500. https://doi.org/10.1111/jlme.12057

Mill JS (2009) On liberty. The Floating Press, Auckland

Miller DG, Dresser R, Kim SYH (2019) Advance euthanasia directives: a controversial case and its ethical implications. J Med Eth 45:84-89. https:// doi.org/10.1136/medethics-2017-104644

Perkins HS (2007) Controlling death: the false promise of advance directives. Ann Intern Med 147(1):51-57. https://doi.org/10.7326/0003-4819-147-1-20070703000008

Post SG (1995) Alzheimer disease and the "then" self. Kennedy Inst Eth J 5(4):307-321. https://doi.org/10.1353/ken.0.0155

Quante M (1999) Precedent autonomy and personal identity. Kennedy Inst Eth J 9(4):365-381. https://doi.org/10.1007/978-94-017-2572-9_22

Rohde K, Peskind ER, Raskind MA (1995) Suicide in two patients with Alzheimer's disease. J Am Geriatr Soc 43:187-189. https://doi.org/10.1111/j.15325415.1995.tb06388.x

De Schweinitz K (1957) Economic growth, coercion, and freedom. World Politics 9(2):166-192. https://doi.org/10.2307/2008878
Stevens A (2005) On coercion. Int J Drug Policy 16:207-209. https://doi.org/ 10.1016/j.drugpo.2005.04.004

Thomasma DC (1991) From ageism to autonomy. In: Binstock RH, Post SG (eds) Too old for health care? Controversies in medicine, law, economics, and ethics. Johns Hopkins University Press, Baltimore, pp. 138-163

Wertheimer A (2002) Liberty, coercion, and the limits of the state. In: Simon RL (ed) The Blackwell guide to social and political philosophy. Blackwell, Malden, pp. $38-59$

Wintrop N (1985) Gaus GF, the Modern Liberal Theory of Man, (London and Canberra, Croom Holm, 1983), pp. 312. Political Sci 37(1):91-92

\section{Acknowledgements}

Peter Wedekind's contribution to the writing of this article was supported by Charles University's grant SVV-260 595 ('Political order in the times of changes'). The support is acknowledged with sincere gratitude. Furthermore, we would like to thank Jana Kunzová for her proofreading services.

\section{Competing interests}

The authors declare no competing interests.

\section{Ethical approval}

This article does not contain any studies with human participants performed by any of the authors.

\section{Informed consent}

This article does not contain any studies with human participants performed by any of the authors.

\section{Additional information}

Correspondence and requests for materials should be addressed to Malte Kayßer or Peter Wedekind.

Reprints and permission information is available at http://www.nature.com/reprints

Publisher's note Springer Nature remains neutral with regard to jurisdictional claims in published maps and institutional affiliations.

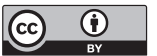

Open Access This article is licensed under a Creative Commons Attribution 4.0 International License, which permits use, sharing, adaptation, distribution and reproduction in any medium or format, as long as you give appropriate credit to the original author(s) and the source, provide a link to the Creative Commons license, and indicate if changes were made. The images or other third party material in this article are included in the article's Creative Commons license, unless indicated otherwise in a credit line to the material. If material is not included in the article's Creative Commons license and your intended use is not permitted by statutory regulation or exceeds the permitted use, you will need to obtain permission directly from the copyright holder. To view a copy of this license, visit http://creativecommons.org/ licenses/by/4.0/.

(C) The Author(s) 2021 